\title{
Comparative leaf micromorphology and anatomy of the dragon tree group of Dracaena (Asparagaceae) and their taxonomic implications
}

\author{
Małgorzata Klimko $^{1} \cdot$ Renata Nowińska $^{1}$ (D) Paul Wilkin² $\cdot$ Justyna Wiland-Szymańska ${ }^{3}$
}

Received: 29 January 2018 / Accepted: 27 June 2018 / Published online: 23 July 2018

(c) The Author(s) 2018

\begin{abstract}
Micromorphological features of the leaf epidermis and the inner structure of leaf tissues of eight arborescent taxa of the genus Dracaena were analysed using light and scanning electron microscopy. The plants are xeromorphic or mesomorphic. Their leaves are isobilateral and amphistomatic, and the stomata are anomocytic and tetracytic. The mesophyll in all the species is divided into an outer chlorenchyma and a central region with colourless water-storage cells, chlorophyll cells and vascular bundles. Water-storage cells have wall bands and reticulate thickenings on the walls. The article describes and illustrates several new quantitative and qualitative leaf characters of the dragon tree group. Our findings can be used to identify the dragon tree group leaves, while the shape of epidermal cells and stomata types may be useful in the identification and classification of fragments of fossil leaves. We conclude that $D$. ombet and D. schizantha are not two distinct species, but should be treated as subspecies of $D$. ombet. Leaf characters, especially stomata depth on adaxial epidermis, height of adaxial epidermal cells and the presence and thickness of hypodermal fibre bundles markedly differ between geographical groups: Macaronesian species (D. draco and D. tamaranae), the species found in East Africa and Arabian Peninsula (D. ombet subsp. ombet, D. ombet subsp. schizantha, D. serrulata and D. cinnabari) and Southeast Asian species (D. kaweesakii and D. jayniana).
\end{abstract}

Keywords Epicuticular layer $\cdot$ Leaf margin $\cdot$ Light microscope $\cdot$ Scanning electron microscope $\cdot$ Stomata Vascular bundle

\section{Introduction}

The genus Dracaena Vand. ex L. is currently classified within the family Asparagaceae, subfamily Nolinoideae (APG III 2009), where together with the closely related genera Sansevieria Thunb. and Pleomele Salisb., Dracaena forms the so-called dracaenoid clade. Taxonomic relations between dracaenoids were a subject of numerous considerations, and both Sansevieria and Pleomele were differently treated in relation to Dracaena: as separate genera Sansevieria (Wiland-Szymanska and Klimko 2005; Jankalski 2009; Mansfeld 2015;

Handling Editor: Mike Thiv.

Renata Nowińska

renata.nowinska@up.poznan.pl

1 Department of Botany, Poznań University of Life Sciences, Wojska Polskiego 71C, 60-625 Poznan, Poland

2 Royal Botanic Garden, Kew, Surrey, Richmond TW9 3AB, UK

3 Department of Plant Taxonomy, Adam Mickiewicz University, Umultowska 89, 61-614 Poznan, Poland
Klimko et al. 2017a, b) and Pleomele (Brown 1914) or as Dracaena sensu lato (Bos 1984, 1998; Staples and Herbst 2005). Another approach was applied by Jankalski (2008), who recommended to include Pleomele in the genus Dracaena and to regard non-Hawaiian and Hawaiian Pleomele as two subgenera of Dracaena (subg. Pleomele Jankal. and subg. Chrysodracon Jankal., respectively). The monophyly of dracaenoids was supported both by molecular analysis (chloroplast DNA sequences) and by morphology: the leaf base pigmentation and bark (APG II 2003; Judd 2003; Judd et al. 2007; Lu and Morden 2010). The red pigments may be related to the dragon tree group's specific mechanism for adaptation to dry and hot environments ( $\mathrm{Lu}$ 2012), but are also known to be a defensive mechanism (Jura-Morawiec and Tulik 2016). A recent phylogenetic study of Lu and Morden (2014) has shown that only six Hawaiian Pleomele species form a monophyletic sister group to the Dracaena species and are separated from them as a distinct genus Chrysodracon P.L.Lu \& Morden. Non-Hawaiian Pleomele are intermixed with Dracaena, whereas Sansevieria is monophyletic but nested within Dracaena.

Species of the genus Dracaena are found in subtropical and tropical regions of the world, but are mainly native to Africa, 
with some in Madagascar, Asia, Socotra, the Mediterranean region, Central America, Micronesia, Northern Australia, and the Pacific islands (Gwyne 1966; Wu and Raven 1994; Bos 1998; Marrero et al. 1998; Staples and Herbst 2005). The variety of occupied habitats corresponds with the relatively large morphological diversity of Dracaena species (Engler 1908; Bos 1998). Numerous perennial, bushy and arborescent species form the understorey beneath the main canopy trees of rainforests worldwide. The arborescent species of Dracaena occur in restricted arid areas and show disjunctive distribution between Macaronesia, Morocco, East Africa, Socotra, the Arabian Peninsula and Thailand (Marrero et al. 1998; Wilkin et al. 2012, 2013). The dragon tree group is formed by 15 arborescent taxa: $D$. draco L. subsp. draco, D. draco subsp. caboverdeana Marrero Rodr. \& R.Almeida and D. tamaranae Marrero Rodr., R.S.Almeida \& Gonz.-Mart. from Macaronesia; D. draco subsp. ajgal Benabid \& Cuzin from Morocco; $D$. ombet Kotschy \& Peyr. and D. ombet subsp. schizantha Baker and D. ellenbeckiana Engl. from north-eastern and east tropical Africa; $D$. serrulata Baker from western and southern Arabian peninsula; $D$. cinnabari Balf.f. from Socotra; $D$. jayniana Wilkin \& Suksathan and D. kaweesakii Wilkin \& Suksathan from Thailand: and D. cambodiana Pierre ex Gagnep., D. yuccifolia Ridl., D. cochinchinensis (Lour.) S.C.Chen as well as D. multiflora Warb. ex P.Sarasin \& Sarasin from Southeast Asia and Pacific islands (Bramwell 1985; Thulin 1995; Bos and Teketay 1997; Marrero et al. 1998; Marrero 2000; Wilkin et al. 2012, 2013; Marrero and Almeida Pérez 2012). Fourteen arborescent species represent the genus Dracaena sensu stricto, while D. multiflora was previously included in the genus Pleomele, as P. multiflora. According to Lu and Morden (2014), arborescent dracaenas are probably not a monophyletic group and arborescence has arisen independently several times as homoplasy. Therefore, one may wonder to what extent the general phenotypic similarity, being the supposed effect of parallel evolution, will be visible in anatomical and micromorphological features. Can the micromorphological and anatomical differences be taxonomically useful? And, finally, do differences at this level correspond with the group's phylogeny?

The morphology of leaves of some dragon tree species has been described by Baker $(1877,1898)$, Miller and Cope (1996), Marrero et al. (1998), Walker (1999) and Wilkin et al. (2012, 2013), whereas leaf micromorphology has been analysed in four dragon tree species by Klimko and WilandSzymańska (2008) and in two species by Denk et al. (2014). Preliminary studies of leaf anatomical structure in D. cinnabari and D. draco were presented by Petroncini et al. (2003) and Nadezhdina et al. (2015).

The main goals of this study were as follows: (1) to describe and document the leaf micromorphology and anatomy of taxa of the dragon tree group, aiming to provide new diagnostic features for their characterization and to determine characters of systematic importance; (2) to supply new data that can be used for identification of extant and fossil species of this group; and (3) to analyse to what extent the differentiation of micromorphological and anatomical features corresponds with the group's phylogeny.

\section{Materials and methods}

\section{Plant material collection}

This study of leaf characters was conducted on living and herbarium specimens. The following taxa were examined: (1) Dracaena draco subsp. draco — cult. BG (066-49-00-10), Germany; cult. BG-AMU (I 1005-001-0000-6986-0357), Poland; (K), Madonn 245, Madeira; (2) D. tamaranaecult. Jardín de Aclimatación de la Orotava, Tenerife (05099), Carine and Santos Guerra 210, from NHM specimens (BM). (3) D. cinnabari-cult. BG (175-01-96-20), Germany; cult. RBG, (4242, 4003), Kew. (4) D. ombet subsp. ombetSudan, Mt. Erkowit, Schweinfurth 250 (K); Ethiopia, Friss et al. 10741 (K); (5) D. ombet subsp. schizantha-Djibouti, Wadi Dounyar, S of Ali Sabieh, Collenette 8644 (K); (6) D. serrulata-Saudi Arabia, South Hijag, between Abha and the Najran plateau, Collenette 1291 (K); Yemen, south side of Sebel Minmar (Sadah-Sagayn), Wood 624 (K); (7) D. jayniana - Thailand, north-eastern: Nong Hin. Distr., Suan Sa Wan, near Ban Suan Hom, Wilkin, Suksathan, Phonsena, Keeratikiat and Tot 1514 (K); Pha Khao Distr., Ban Phoem, Wat Tham, Pha Sawan, Wilkin, Suksathan, Phonsena, Keeratikiat and Tot 1519 (K); central: Lop Buri Province, Lam Son Ti, Khao Wong Chan Daeng, Wilkin, Suksathan, Phonsena, Triboun, Keeratikia and Plataan 1501 (K); (8) D. kaweesakii-Thailand, northern: Chiang Rai, Mae Sai, Doi Pha Mi/ Doi Nang Non/Khun Nan Nang Non, Wilkin, Suksathan and Wongnak 1507 (K); Mae Sao, Doi Ang Khang Royal Project, cult. Bonsai Garden Nursery, Wilkin, Suksathan, Wongnak and Sumit 1505 (K); north-eastern: Loei, Nong Hin, near Ban Suan Hom, Wilkin, Suksathan, Phonsena, Keeratikiat and Tot 1517 (K); central: Lop Buri Province, Lam Son Ti, Khao Wong Chan Daeng, Wilkin, Suksathan, Phonsena, Triboun, Keeratikia and Plataan 1500 (K).

\section{Microscopic analyses}

Middle parts of 3-5 mature leaves of each individual were examined for micromorphology and anatomy. Completely dried leaves were investigated under a scanning electron microscope (SEM). Micrographs were taken using an EVO $40 \mathrm{SEM}$ at an accelerating voltage of $15 \mathrm{kV}$, at the Confocal and Electron Microscopy Laboratory, Faculty of Biology, Adam Mickiewicz University, Poznań, Poland. Prior to observations the prepared material was sputtered (for 10-15 s) 
with gold using an SCB 050 ion sputter. The traits studied in SEM were as follows: shape of epidermal cells, stomata types and the sculpture of wax and cuticle on adaxial and abaxial surfaces of the leaves. Living material was preserved in $70 \%$ ethanol for anatomical investigations. Herbarium specimens were rehydrated by boiling in water for 10-20 $\mathrm{min}$. Transverse sections of $50 \mu \mathrm{m}$ thickness were obtained using a microtome (Leitz). Ten sections were taken from the middle parts of leaf blades. All the sections were embedded in glycerine-gelatin and examined under an Olympus BX 43 light microscope equipped with a camera. Then slides were prepared and used to describe transverse sections (T.S.), and traits measured. We studied the following anatomical features: cuticle thickness of adaxial and abaxial epidermal cells, height of adaxial and abaxial epidermal cells, width of adaxial and abaxial epidermal cells, hypodermal fibre thickness, phloem fibre thickness, diameter of vascular bundle and stomata depth (on adaxial epidermis). Stomatal depth was measured from the cuticle surface to the top of the upper cuticular ledge, the thickness of the lamina was measured between the adaxial and abaxial surface, while the thickness of the midrib area was determined in the thickest part of the leaf. Standard terminology mainly follows Barthlott (1981, 1990) and Barthlott et al. (1998) for surface sculpturing patterns.

\section{Statistical analyses}

Discriminant function analysis (DFA) was used to determine which of the above-mentioned quantitative features best differentiate the examined species. The model was built on logarithmically transformed data with a backward stepwise procedure. The contributions of particular characters to the discrimination between groups were interpreted based on total canonical structure, i.e. correlations between characters and discriminant axes. Differences between populations for characters provided by discriminant function analysis were subsequently tested with the analysis of variance (ANOVA). Statistical analyses were performed using Statistica, version 11 (StatSoft, Poland).

\section{Results}

\section{Morphological and anatomical descriptions and interpretations}

\section{Leaf margin and epidermal cells (Figs. 1, 2, 3)}

Leaf margin is entire and reddish in Dracaena draco, entire in D. tamaranae (Fig. 1a, b), entire with a distinctive narrow white margin when fresh in D. kaweesakii, entire and undulate widely in $D$. ombet subsp. ombet (Fig. 1c), serrulate in D. ombet subsp. schizantha and $D$. serrulata (Fig. 1d, e), dentate in D. cinnabari (Fig. 1f), while dentate or spiny with sharp stiff points in D. jayniana (Fig. 1g, h). The shape of epidermal cells and the anticlinal walls is similar on both leaf surfaces. The cells are long or short, rectangular or polygonal, elongated and parallel to the leaf axis (Figs. 2, 3). The anticlinal walls between epidermal cells are depressed below the outer tangential surface of the cells. The periclinal walls are more or less convex (Figs. 2, 3). Cuticular ornamentation is glabrous without trichomes on both surfaces. Typically, the cuticle is smooth, but in $D$. ombet (both subspecies) and in D. cinnabari, wart-like elevations (papillae) can be observed (Figs. 1c, d, f, 2d). In D. draco, irregular cuticular thickenings are visible (Fig. 1a). SEM revealed a micromorphological diversity of leaf epicuticular waxes. In D. draco and D. tamaranae, the layers of wax are oriented parallel to each other, and parallel or perpendicular to the cuticle surface (Fig. 3a, b). In the other species, epicuticular waxes formed platelets with no distinct fibrillar structures (Figs. 2c-h, 3c-h). SEM observations showed no differences in wax morphology between the adaxial and abaxial surfaces. Leaves of the studied taxa are uniformly amphistomatic. The stomata of $D$. draco and $D$. kaweesakii are anomocytic (Figs. 2a, h, 3a, h), whereas the other species have tetracytic stomata (Figs. 2b-g, 3b-g). Leaves show remarkable variation in the distribution of stomata in the surface view under SEM (Figs. 2, 3). In $D$. cinnabari, the subsidiary cells on both sides of the stoma are depressed and covered with a thin cuticle (Figs. 1f, $2 \mathrm{f}, 3 \mathrm{f}$ ) and this distinguishes the species from the other studied taxa. Stomata on both surfaces are distributed in rows forming bands (Fig. 2a, b, g), arranged parallel to the leaf axis over the entire area regularly (Fig. 2d, f) or irregularly (Fig. 2c, e, h). Stomata are slightly (Fig. 2a) or deeply sunken (Figs. 2b-g, 3b-g) and are surrounded (Figs. 2b-d, f, g, 3b-d, f, g) or not (Figs. 2e, h, 3e, h) with cuticular thickenings forming a rim-either square, oval or rectangular in outline (Figs. 2b-d, g, 3b-d, f, g). In $D$. kaweesakii, stomata are located at the level of the other epidermal cells on both surfaces (Figs. $2 \mathrm{~h}, 3 \mathrm{~h}$ ).

\section{Lamina transverse section (T.S.) (Table 1, Figs. 4, 5)}

Outline: The lamina surface in the T.S. on both surfaces is almost flat in D. draco (Fig. 4a) and D. kaweesakii (Fig. 4p, q), flat or slightly undulate in D. cinnabari (Fig. 4k), and slightly undulate in both subspecies of $D$. ombet (Fig. 4e, g) and D. serrulata (Fig. 4i). In D. jayniana the lamina in the T.S. is slightly undulate on the adaxial surface, with mounds on the abaxial surface (Fig. $4 \mathrm{~m}, \mathrm{n}$ ). In D. tamara$n a e$, the blade is canaliculate and grooved (Figs. 2b, 4c). The thickness of laminae ranges from $0.4 \mathrm{~mm}$ to $3.0 \mathrm{~mm}$. The midrib region in the T.S. is usually more or less D-shaped (except for D. tamaranae and some specimens of D. draco, 

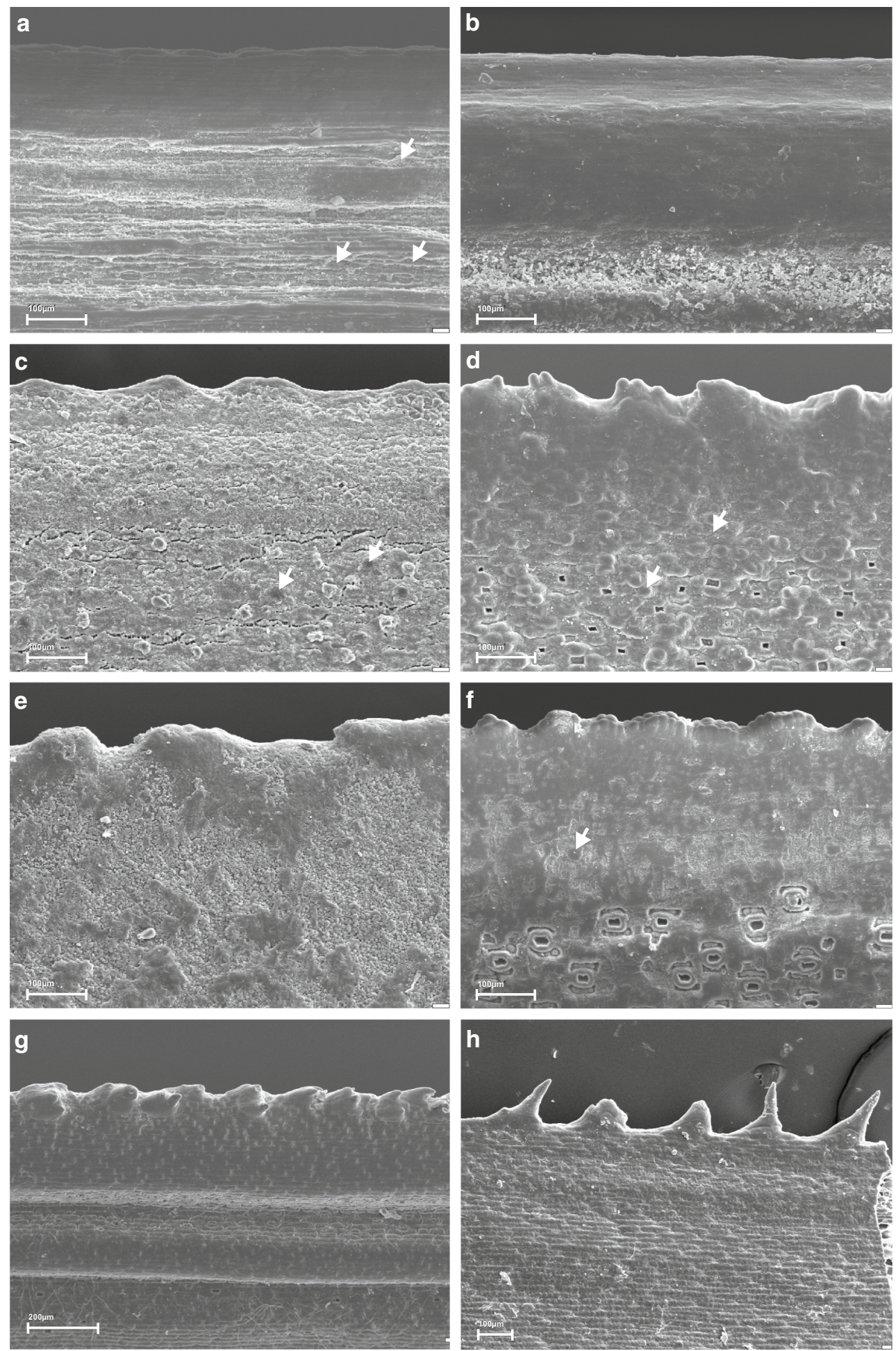

Fig. 1 SEM photographs on the adaxial leaf side and margins of Dracaena. a Dracaena draco, portion of irregular entire leaf margin, irregularly thickened cuticle (arrows); b $D$. tamaranae, portion of entire leaf margin; c $D$. ombet subsp. ombet, wide wavy leaf margin, papillate epidermal cells (arrows); d D. ombet subsp. schizantha, ser- rulate leaf margin, papillate epidermal cells (arrows); e D. serrulata, wavy and serrulate leaf margin; f $D$. cinnabari, overview showing serrulate leaf margin, papillate epidermal cells (arrow); g, h D. jayniana, different trichomes on leaf margin (specimens 1514 and 1519, respectively) 

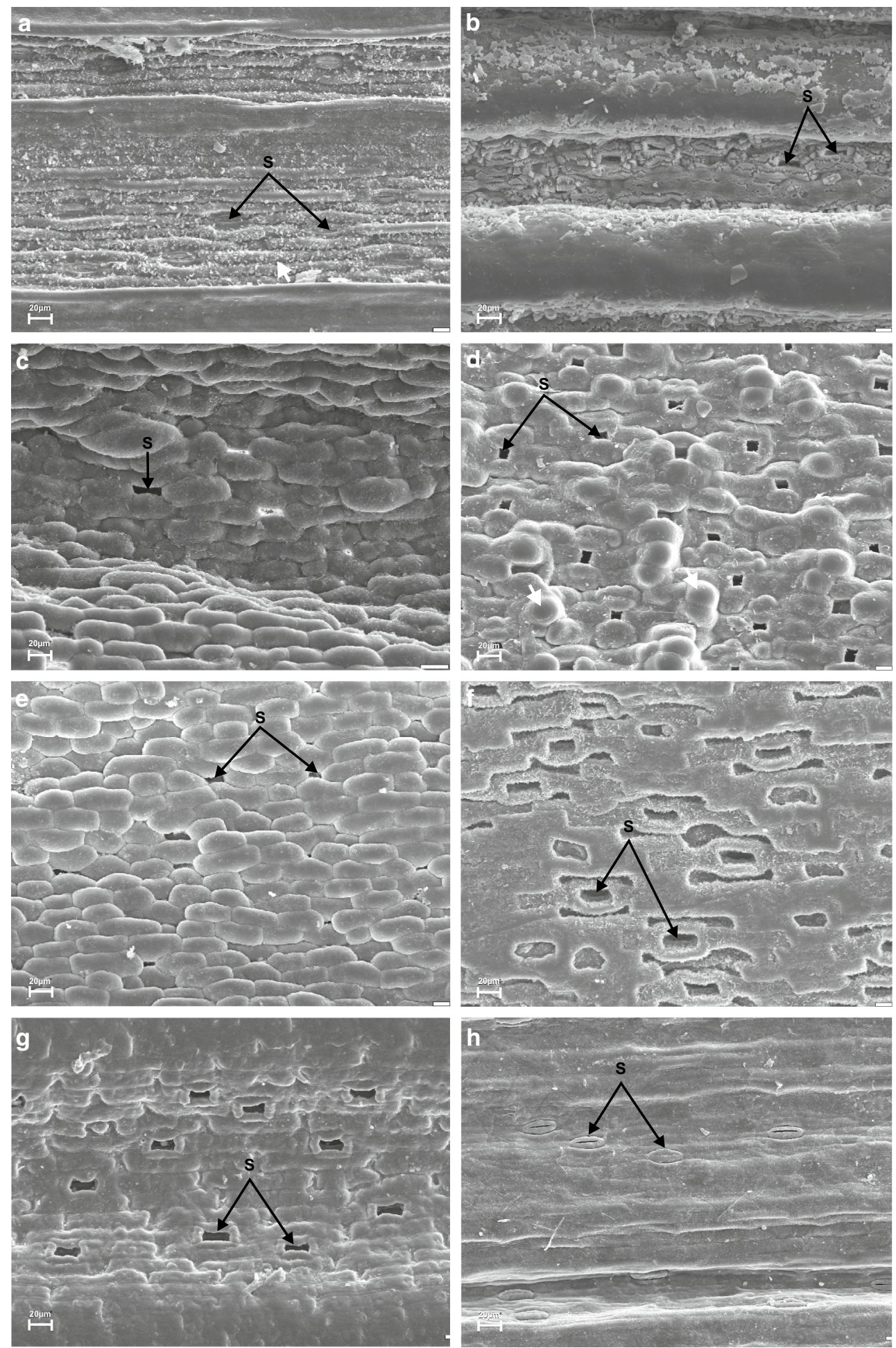

Fig. 2 SEM photographs on the adaxial leaf side of Dracaena. a Dracaena draco, overview showing alternation of stomata-free bands and bands containing stomata (arrows); b D. tamaranae, overview showing alternation of stomata-free bands and bands containing stomata; $\mathbf{c}$ $D$. ombet subsp. ombet, slightly papillate epidermal cells, thickening of stomata; d D. ombet subsp. shizantha, papillate epidermal cells, thickening of stomata; e D. serrulata, non-papillate epidermal cells, sunken stomata; f $D$. cinnabari, overview showing equally distributed, densely arranged stomata, thickening of epidermis and stomata; g D. jayniana, overview showing alternation of stomata-free bands and bands containing stomata; $\mathbf{h}$ D. kaweesakii, overview showing scattered distribution of stomata, non-papillate epidermal cells (specimen 1505) 

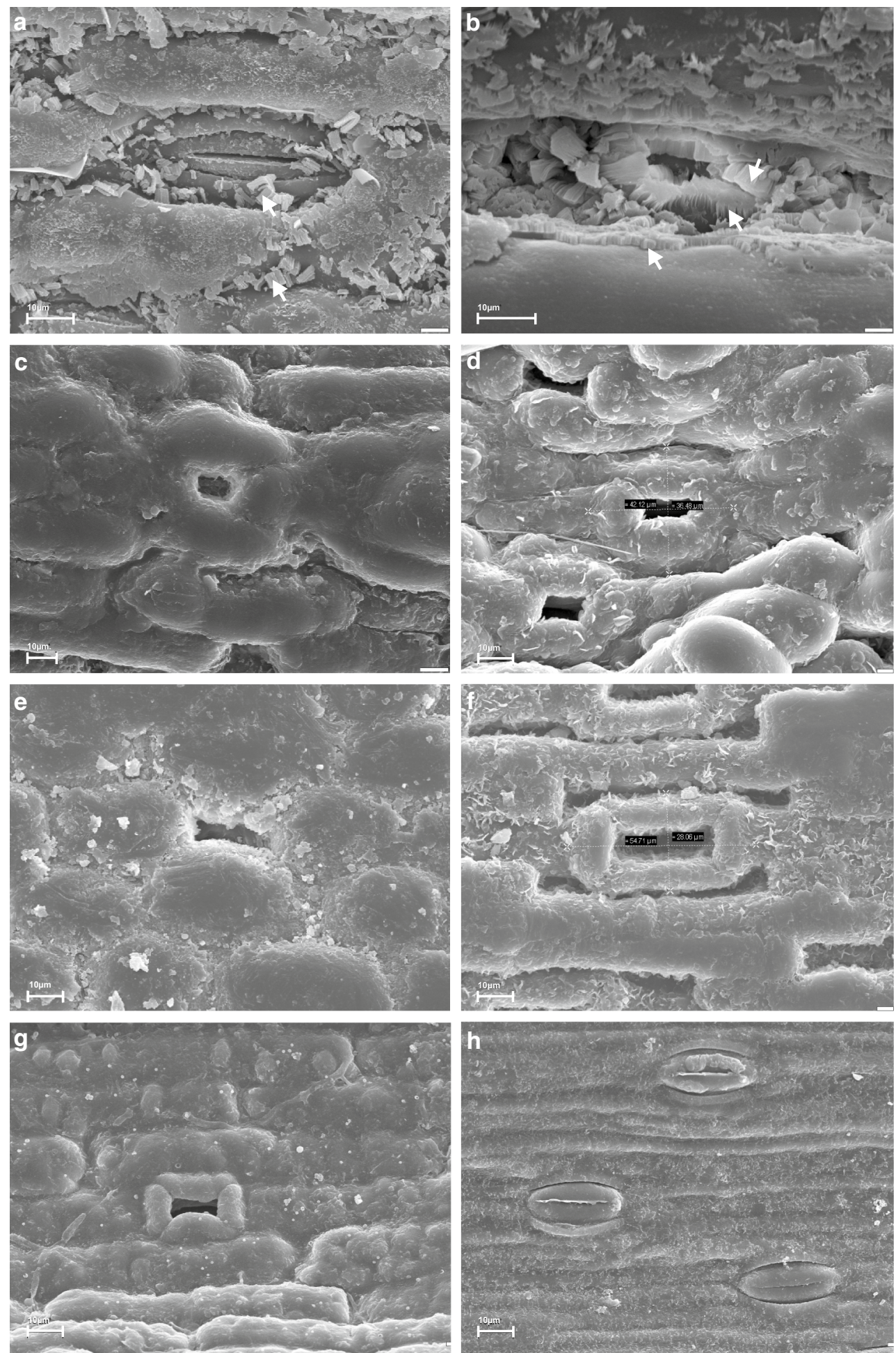

Fig. 3 SEM photographs of stomata on the abaxial leaf side of Dracaena. a Dracaena draco, layers of wax are oriented parallel to each other, and parallel or perpendicular to the cuticle surface (arrows); $\mathbf{b}$ D. tamaranae; layers of wax are oriented parallel; epicuticular waxes lost contact with the cuticle revealing the basal side of wax (arrows); c $D$. ombet subsp. ombet, stoma with cuticular rim; $\mathbf{d} D$. ombet subsp. schizantha, stoma with cuticular rim; e. D. serrulata, stoma without cuticular rim; f $D$. cinnabari, stoma with cuticular rim and thick cuticle; $\mathbf{g}$ D. jayniana, stoma with rectangular cuticular rim; h D. kaweesakii, stomata are located at the level of the other epidermal cells 


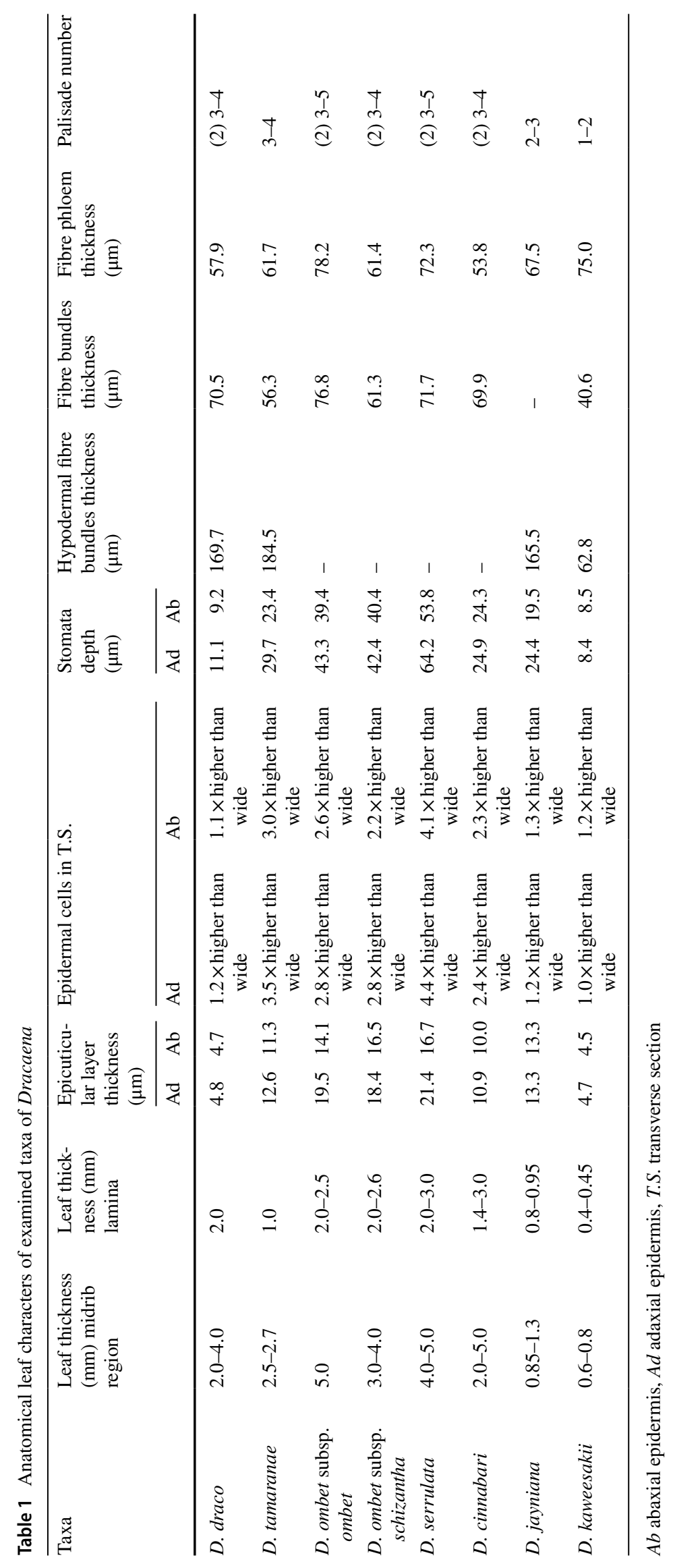


D. jayniana and D. kaweesakii) and D- or V-shaped (young leaves) in D. cinnabari, with the thickness of the midrib area ranging from $0.6 \mathrm{~mm}$ to $5.0 \mathrm{~mm}$.

Cuticle: In all taxa the cuticle on the adaxial epidermis is thicker (on average 4.7-21.4 $\mu \mathrm{m}$ ) than on the abaxial epidermis $(4.5-16.7 \mu \mathrm{m})$.

Epidermis: In all the taxa the leaf epidermis consists of a single layer of cells (Fig. 4). The epidermal cells are square to rectangular in outline. Those on the adaxial leaf surface are larger than those on the abaxial surface. Significant differences between the examined taxa are observed in the shape of epidermal cells in T.S. (Fig. 4, on the right). The heightto-width ratio in epidermal cells varies between the examined species, ranging from 1.0 to 4.4 in the adaxial epidermis and from 1.1 to 4.1 in the abaxial epidermis (Table 1). The epidermal cell walls on both surfaces are regularly or unevenly thickened, either straight or straight and slightly undulated, while the outer epidermal walls in T.S. are more or less convex, smooth or papillate (Fig. 4, on the right). The leaf epidermis in the T.S. view varies in stomatal depth as well as cuticle flange development (top and bottom) (Fig. 4, on the right). The average stomatal depth in the adaxial epidermis ranges from 8.4 to $64.2 \mu \mathrm{m}$, while in the abaxial epidermis it varies from 8.5 to $53.8 \mu \mathrm{m}$. In D. tamaranae, stomata are found only in leaf depressions (Fig. 4c, d).

Hypodermis: In four species, i.e. D. draco, D. tamaranae, $D$. jayniana and D. kaweesakii, hypodermal fibre bundles are found and their thickness ranges from 62.8 (D. kaweesakii) to $184.5 \mu \mathrm{m}$ (D. tamaranae) (Fig. 4a-d, m-r). All fibre bundles run parallel, and the cell walls have thick, lignified, secondary walls.

Mesophyll: The leaves are isobilateral. The mesophyll in all taxa is divided into an outer region of chlorenchyma and a central region of non-photosynthetic water-storage tissue, which is clearly distinct from the peripheral mesophyll (Fig. 4, on the left). The mesophyll comprises 2-5 layers of palisade parenchyma (chlorenchyma). However, 2-5 layers of palisade cells, e.g. in $D$. ombet subsp. ombet, could be found simultaneously in a single leaf. The cells of palisade parenchyma are vertically elongated and contain many chloroplasts. Central mesophyll, with very small intercellular air spaces, is located between the palisade parenchyma of the adaxial and abaxial surfaces of the leaf blade. All species contain the water-storage tissue in their central mesophyll region, consisting of living mesophyll cells with small plastids and several dead water-storage cells, with strips or reticulate thickenings on the walls, e.g. in D. tamaranae and D. kaweesakii (Fig. 5). Fibre bundles are found in the mesophyll. They are located between the chlorenchyma and the central mesophyll (Fig. 4e, g, i, k) or in the central mesophyll. In the central mesophyll the thickness of fibre bundles varies, as they sometimes consist of only a few cells in the T.S. The average thickness of fibre bundles ranges from
$40.6 \mu \mathrm{m}$ in $D$. kaweesakii to $76.8 \mu \mathrm{m}$ in $D$. ombet subsp. ombet. In D. jayniana, no fibre bundles are observed in the mesophyll (Fig. 4m, n). Moreover, in D. draco, D. tamaranae and $D$. jayniana, leaf edges are strengthened with sclerenchyma cells (Fig. 4a, c, m, n).

Vascular bundles: In T.S., vascular bundles are collateral and consist of a well-developed sclerenchyma cap above the phloem, conducting elements of phloem and xylem, xylem parenchyma cells and xylem sclerenchyma cells. In D. tamaranae and in both subspecies of $D$. ombet, sclerenchyma is well developed (Fig. 5b, c). Vascular bundles are surrounded by parenchymatous bundle sheaths (Figs. 4 , on the left, 5) and either run parallel (Fig. 4c, m, n, p) or are scattered throughout the mesophyll (Fig. 4a, e, g, i, k). The vascular bundles in all the taxa are oval in outline in T.S.; the length of their long axis in the lamina ranges between 114 (D. draco) and $380.0 \mu \mathrm{m}(D$. ombet subsp. ombet), while in the midrib region it is between 252.3 (D. kaweesakii) and $514.6 \mu \mathrm{m}$ (D. ombet subsp. ombet). In primary veins (Fig. 4, on the left) the phloem is oriented towards the nearest leaf margin, whereas in the midrib region it is oriented towards the abaxial side (Fig. 5). In secondary veins the phloem is oriented towards the nearest leaf surface. The vascular bundles have well-developed sclerenchyma cells above the phloem and range in thickness from 53.8 (D. cinnabari) to $78.2 \mu \mathrm{m}$ (D. ombet subsp. ombet) (Table 1). In both subspecies of $D$. ombet, phloem of the largest vascular bundle in the midrib region is separated by sclerenchyma cells (Fig. 5c). Calcium oxalate crystals are represented by raphides in all species, and they are present in the chlorenchyma and the central mesophyll with varying frequency (Fig. 4g, i, p).

\section{Results of statistical analyses}

The analysis of variance revealed significant differences $(p<0.0003)$ in all the anatomical characters in Dracaena species. Discriminant function analysis of 10 quantitative characters yielded tree components, accounting for $100 \%$ of the total variance in the data set. Eighty percentage of all discriminatory power is explained by the first canonical function (DF1). The characters that are strongest correlated $(r>0.4)$ with the functions are stomata depth on adaxial epidermis and the height of adaxial epidermal cells (DF1), thickness of hypodermal fibre bundles (DF2 and DF3) as well as the width of adaxial and abaxial epidermal cells (DF3) (Table 2). Function DF1 discriminates mostly between D. draco, D. kaweesakii and D. serrulata; DF2 distinguishes mostly between $D$. kaweesakii and D. cinnabari versus $D$. tamaranae, whereas DF3, between $D$. jayniana and $D$. kaweesakii. The scatter plot for the first two discriminant functions shows three groups of species, which quite clearly corresponds to the geographical distribution of dragon tree species (Fig. 6). On the right side of 

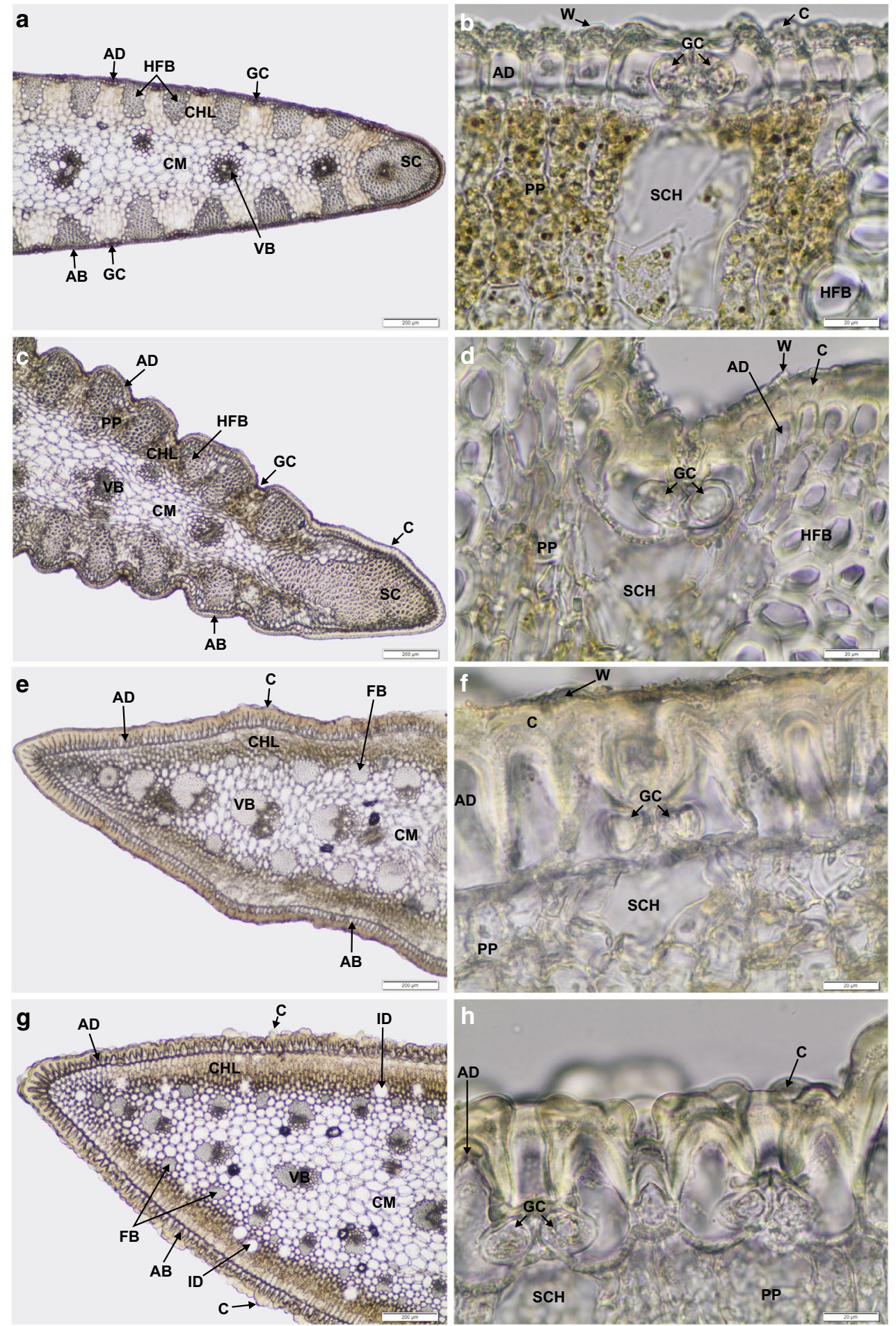

Fig. 4 Light microscope. Part of leaf transverse section (on the left) and adaxial epidermis, higher magnification (on the right) of Dracaena. a, b Dracaena draco $; \mathbf{c}, \mathbf{d} D$. tamaranae; $, \mathbf{e}, \mathbf{f} D$. ombet subsp. ombet $; \mathbf{g}, \mathbf{h}$ D. ombet subsp. schizantha; $\mathbf{i}, \mathbf{j}$ D. serrulata $; \mathbf{k}, \mathbf{l}$ D. cinnabari $; \mathbf{m}, \mathbf{n}, \mathbf{o}$ D. jayniana; $, \mathbf{p}, \mathbf{q}, \mathbf{r} D$. kaweesakii. Abbreviations:

$A B$ abaxial epidermis; $A D$ adaxial epidermis; $C$ cuticle; $C H L$ chlorenchyma; $C M$ central mesophyll; $F B$ fibre bundle; $G C$ guard cells; $H F B$ hypodermal fibre bundle; $I D$ idioblast; $P P$ palisade parenchyma; $P S$ parenchymatous bundle sheath; $S C$ sclerenchymatous cells; $W$ wax; $V B$ vascular bundle; $X$ xylem 

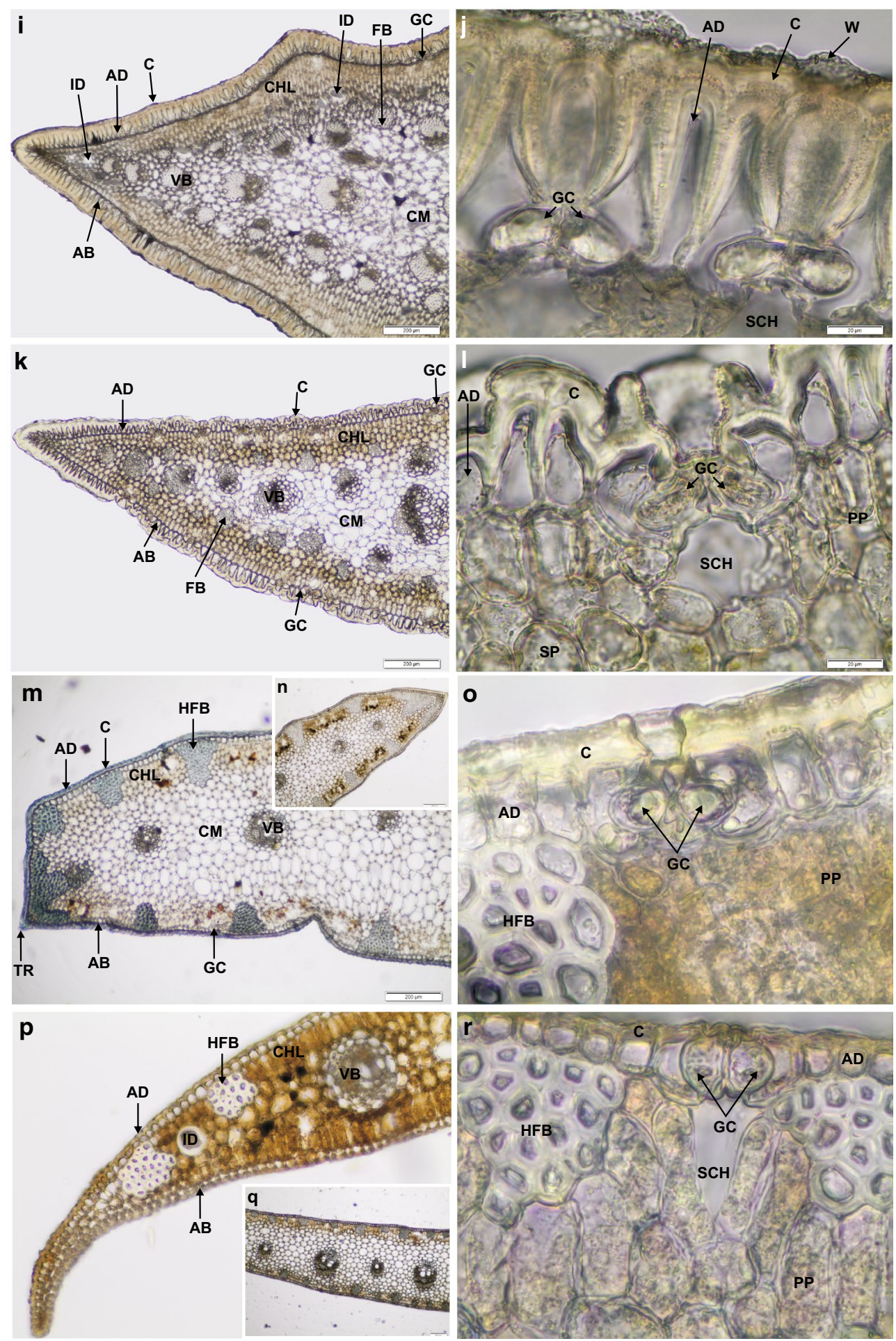

Fig. 4 (continued)

the plot there is the biggest group comprising the Dracaena species from Asia and Africa (D. ombet subsp. ombet, D. ombet subsp. schizantha, D. serrulata and D. cinnabari). On the left side there are two groups: one of the Thailand species (D. jayniana and D. kaweesakii) and one of the Macaronesian species (D. draco and D. tamaranae), which are slightly separated by the second canonical function. 

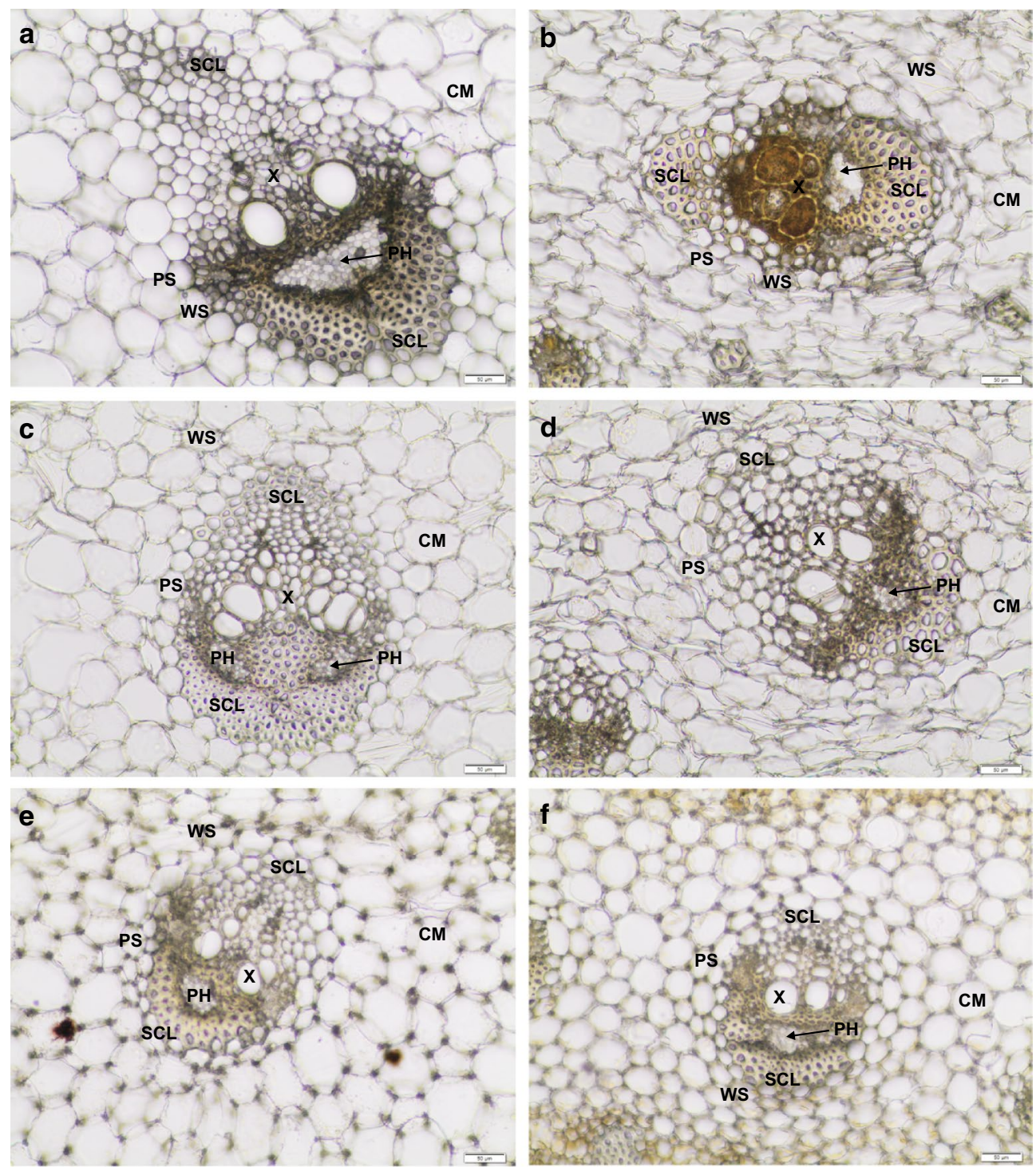

Fig. 5 Light microscope. Transverse section of vascular bundle in the midrib region of Dracaena. a Dracaena draco; $\mathbf{b} D$. tamaranae; c $D$. ombet subsp. schizantha; d D. cinnabari; e D. jayniana; f $D$. kawee-

sakii. Abbreviations: $C M$ central mesophyll; $P H$ phloem; $P S$ parenchymatous bundle sheath; $S C$ sclerenchymatous cells; $W S$ water-storage cells with wall bands; $X$ xylem

\section{Discussion}

This paper presents for the first time a comparative micromorphological and anatomical study of leaves of the eight arborescent Dracaena taxa. The results of the study show that the anatomical and micromorphological characters vary among the investigated species and they are taxonomically useful. Among the anatomical features, the height and width of epidermal cells, stomata depth as well as the presence and thickness of hypodermal fibres seem to be the most useful as diagnostic features. Some micromorphological characters, such as wax ornamentation and cuticular membrane, distribution and location of stomata,

the presence or absence of raised outer stomatal rims, could also be used for delimiting the examined species.

According to Marrero et al. (1998), D. draco and D. tamaranae differ in leaf shape, width and curvature. Our study shows further differences, i.e. in thickness of the epicuticular layer, size and shape of epidermal cells, depth of stomata and the thickness of hypodermal fibre bundles. The cited authors reported also that $D$. draco is closely related to $D$. cinnabari. These species are morphologically similar, but $D$. draco usually has slightly succulent and flexible leaves with reddish entire leaf margin, while $D$. cinnabari has very succulent and rigid leaves, with the leaf margin finely dentate towards the base. Differences in succulence observed in T.S. primarily concern the height-to-width 
Table 2 Results of the discriminant function analysis of the eight dragon tree taxa and a comparison of the taxa by ANOVA

\begin{tabular}{|c|c|c|c|c|c|c|c|c|}
\hline \multirow[t]{3}{*}{ Characters } & \multicolumn{6}{|c|}{ Discriminant function analysis (DFA) } & \multicolumn{2}{|l|}{ ANOVA } \\
\hline & \multirow[t]{2}{*}{ Wilks' lambda } & \multirow{2}{*}{$\begin{array}{l}\text { Partial } \\
\text { Wilks' } \\
\text { lambda }\end{array}$} & \multirow[t]{2}{*}{$p$ value } & \multicolumn{3}{|c|}{ Factor structure matrix } & \multirow[t]{2}{*}{$F$ values } & \multirow[t]{2}{*}{$p$ value } \\
\hline & & & & DF 1 & DF 2 & DF 3 & & \\
\hline Cuticle thickness of adaxial epidermal cells & 0.0001 & 0.66 & 0.00 & 0.31 & -0.27 & -0.13 & 93.97 & 0.0000 \\
\hline Cuticle thickness of abaxial epidermal cells & 0.0001 & 0.74 & 0.01 & 0.19 & -0.17 & -0.28 & 54.13 & 0.0000 \\
\hline Height of adaxial epidermal cells & 0.0002 & 0.60 & 0.00 & 0.44 & 0.14 & -0.15 & 68.77 & 0.0000 \\
\hline Width of adaxial epidermal cells & 0.0002 & 0.53 & 0.00 & 0.04 & 0.26 & -0.55 & 25.96 & 0.0000 \\
\hline Height of abaxial epidermal cells & 0.0001 & 0.78 & 0.02 & 0.39 & 0.05 & 0.07 & 62.68 & 0.0000 \\
\hline Width of abaxial epidermal cells & 0.0002 & 0.56 & 0.00 & 0.06 & 0.28 & -0.48 & 28.70 & 0.0000 \\
\hline Hypodermal fibre thickness & 0.0005 & 0.21 & 0.00 & -0.37 & -0.56 & -0.55 & 1482.02 & 0.0000 \\
\hline Fibre phloem thickness & 0.0001 & 0.83 & 0.09 & 0.06 & -0.08 & 0.25 & 4.86 & 0.0002 \\
\hline Diameter of vascular bundle & 0.0002 & 0.61 & 0.00 & 0.07 & -0.12 & 0.02 & 12.00 & 0.0000 \\
\hline Stomata depth (adaxial epidermis) & 0.0003 & 0.38 & 0.00 & 0.56 & -0.38 & -0.04 & 246.01 & 0.0000 \\
\hline Eigenvalues & - & - & - & 49.5 & 12.0 & 2.27 & - & - \\
\hline Cumulative proportions & - & - & - & 0.8 & 0.9 & 1.0 & - & - \\
\hline
\end{tabular}

Values for which the discriminant functions are most weighted are shown in bold

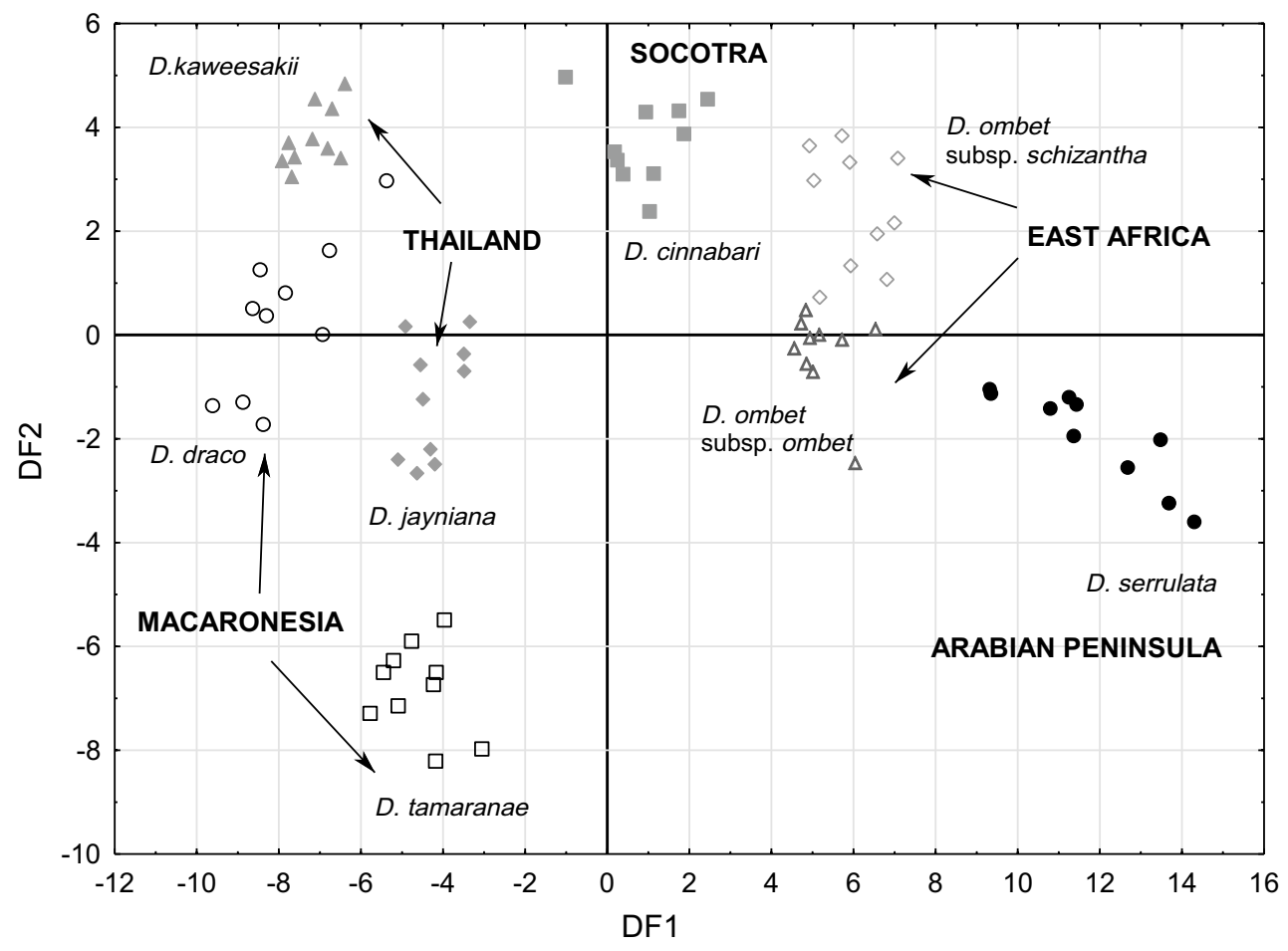

Fig. 6 Biplot of discriminant function analysis of the eight dragon tree taxa of Dracaena

ratio of epidermal cells, thickness of epidermal cells, cuticle thickness and stomatal depth. Based on SEM images, additional remarkable differences were observed between D. draco and D. cinnabari in the micromorphological leaf features, i.e. wax type, the distribution and location of stomata, the shape of the outer stomatal thickenings, or the size of epidermal cells (Klimko and Wiland-Szymańska 2008). In $D$. draco, chlorenchyma is interrupted by hypodermal fibre bundles, which is consistent with the data reported by Rudall et al. (2000), and it is very similar in terms of this trait to D. tamaranae, D. kaweesakii and D. jayniana, as well as D. ellenbeckiana and D. yuccifolia (Klimko et al. unpubl. 
data). In $D$. cinnabari, only fibre bundles are present. The distribution of sclerenchyma cells in the leaf is of considerable taxonomic value. According to Marrero et al. (1998), $D$. tamaranae is closely related to the three taxa of Eastern Africa and Arabian Peninsula (D. ombet subsp. ombet, D. ombet subsp. schizantha and D. serrulata). All these species have glaucous leaves and minute bracteoles and are not densely branched. These continental species have smaller flowers and inflorescences than those of $D$. tamaranae. Our results show clear differences between these species, i.e. in leaf surface, type of wax, distribution and location of stomata, thickness of epidermal layers and the presence of hypodermal fibre bundles.

Regarding D. ombet subsp. ombet and D. ombet subsp. schizantha, our results showed some differences, e.g. in leaf margins. In turn, Täckholm (1956) stated that leaves of $D$. ombet from Egypt have a thick, denticulate margin, while Thulin (1995) and Collenette (2000) reported that those from Somalia and Saudi Arabia have entire margins. Bos and Teketay (1997) observed that $D$. ombet plants growing on granite (Ethiopia and Eritrea) have leaves with entire margins. Differences of potential taxonomic significance were found in the protrusive secondary sculpture-distinct papillae, cuticular layer, a very well-developed stomatal rim and more stomata on both surfaces in $D$. ombet subsp. schizantha (Klimko and Wiland-Szymańska 2008). However, regarding the anatomical features, the two subspecies are very similar. Miller (1988) stated that in D. serrulata leaf margins may be entire or minutely serrulate, and Collenette (2000) reported that its leaves had minutely serrate margins, but our material had serrulate margins. Some micromorphological leaf features in D. serrulata distinguished it from all the other species, i.e. deeply sunken stomata without an outer cuticular rim.

Two Macaronesian (D. draco and D. tamaranae) and two Thailand species (D. kaweesakii and D. jayniana) are anatomically similar, e.g. in the presence of hypodermal fibre bundles, but differ in the morphological type of wax.

Species of the dragon tree group are regarded as succulent (Marrero et al. 1998; Rudall et al. 2000; Petroncini et al. 2003). Prychid and Rudal (1999) demonstrated that the occurrence and distribution of calcium oxalate crystals can be useful for taxonomic purposes in monocotyledons, but we found calcium oxalate crystals in the chlorenchyma and central mesophyll in all taxa.

Discriminant function analysis showed that leaf epidermal and subepidermal quantitative characters markedly differ between geographical groups: the Macaronesian species (D. draco and D. tamaranae), the species found on the crossroads of Asia and Africa (D. ombet, D. serrulata and D. cinnabari) and the Southeast Asia (Thailand) species
(D. kaweesakii and D. jayniana). These results do not fully coincide with the phylogenetic systematics of dracaenoids presented by Lu (2012) and Lu and Morden (2014). Reconstruction of arborescent versus bushy habit showed a distant position of Thailand species and relationship between $D$. draco and $D$. serrulata, which are not reflected in differentiation of morpho-anatomical characters of these species. On the other hand, our study supports the previous findings of Marrero et al. (1998) that the dragon tree group provides an example of two major biogeographical disjunctions between West and East Africa. The differences between those groups of Dracaena (W Africa vs. E Africa) concern the height of epidermal cells and the depth of stomata, so they could be caused by environmental pressure and result from species adaptation to hotter and more dry climate on the continent (D. serrulata, D. ombet and D. schizantha), compared to the more humid climate on the islands ( $D$. draco and $D$. tamaranae).

Characters of the leaf epidermis and anatomy of the studied species are not constant in the whole Dracaena genus (Wiland-Szymańska and Klimko 2005; Klimko and WilandSzymańska 2008; Denk et al. 2014). According to our study, the bushy taxa (i.e. D. aubryana Brongn. ex É. Morren, $D$. deremensis Engl., D. fragrans (L.) Ker Gawl., D. marginata Lam., D. multiflora, and D. reflexa Lam.) differ from arborescent ones by clearly mesomorphic leaf structure, i.e. dorsiventral leaves, thinner epidermis and wax layer, no hypodermal fibres, smaller depth of stomata. It is possible that in the group of bushy Dracaena some of the anatomical features of leaves would be of taxonomic significance for species determination. However, our observations will have to be verified by further in-depth studies.

Acknowledgements We would like to express our gratitude to Ilona Wysakowska for technical assistance in leaf anatomy analyses and to Wojciech Klimko for assistance with computer recording. The authors would like to thank two anonymous reviewers for their suggestions and comments made on an earlier version of the manuscript. This study was carried out with financial support from the National Science Center (Grant No. N N303 807540) and the Department of Botany, the Poznań University of Life Sciences, and funds for Special Experimental Establishment "Botanical Garden" of the Faculty of Biology, the Adam Mickiewicz University in Poznań.

\section{Compliance with ethical standards}

Conflict of interest The authors declare that they have no conflict of interest.

Open Access This article is distributed under the terms of the Creative Commons Attribution 4.0 International License (http://creativeco mmons.org/licenses/by/4.0/), which permits unrestricted use, distribution, and reproduction in any medium, provided you give appropriate credit to the original author(s) and the source, provide a link to the Creative Commons license, and indicate if changes were made. 


\section{References}

Apg II (2003) An update of the Angiosperm Phylogeny Group classification for the orders and families of flowering plants: APG II. Bot J Linn Soc 141:399-436. https://doi.org/10.1046/j.1095-8339.2003. t01-1-00158.x

Apg III (2009) An update of the Angiosperm Phylogeny Group classification for the orders and families of flowering plants; APG III. Bot J Linn Soc 161:105-121. https://doi.org/10.111 1/j.1095-8339.2009.00996.x

Baker JG, Moore SM (1877) Descriptive notes on a few of Hildebrandt's East African Plants. J Bot 6: 65-72

Baker JG (1898) Liliaceae: Dracaena. In: Thiselton-Dyer WT (ed) Flora of Tropical Africa, Hydrocharideae to Liliaceae. L. Reeve \& Co., Ashford, Kent, pp 436-450

Barthlott W (1981) Epidermal and leaf surface characters of plants: systematic applicability and some evolutionary aspects. Nordic J Bot 1:345-354

Barthlott W (1990) Scanning electron microscopy of the epidermal surface in plants. In: Claugher D (ed) Scanning electron microscopy in taxonomy and functional morphology, Systematic Association Special, vol. 41. Clarendon Oxford, Oxford, pp 69-94

Barthlott W, Neinhuis C, Cutler D, Ditsch F, Meusel I, Theisen I, Wilhelmi H (1998) Classification and terminology of plant epicuticular waxes. Bot J Linn Soc 126:237-260

Bos JJ (1984) Dracaena in West Africa. Agricultural University Wageningen, Wageningen

Bos JJ (1998) Dracaenaceae. In: Kubitzki K (ed) The families and genera of flowering plants, monocotyledons, lilianae (Except Orchidacea). Springer, Berlin, pp 238-241

Bos JJ, Teketay D (1997) Dracaenaceae. In: Edwards S (ed) Flora of Ethiopia and Eritrea, vol. 5. Uppsala University, Uppsala, pp 76-84

Bramwell D (1985) Contribución a la biogeografia de las Islas Canarias. Bot Macaronés 14:3-34

Brown NE (1914) Notes on the genera Cordyline, Dracaena, Pleomele, Sansevieria, and Taetsia. Bull Misc Inform Kew 8:273-279

Collenette IS (2000) Dracaena in Saudi Arabia. Brit Cactus Succ J 18:33-37

Denk T, Güner HT, Grimm GW (2014) From mesic to arid: leaf epidermal features suggest preadaptation in Miocene dragon trees (Dracaena). Rev Palaeobot Palynol 200:211-228

Engler A (1908) Die Pflanzenwelt Afrikas inbosondere seiner tropischen Gebiete. Grundzüge der Phlanzenverbreitung in Afrika und die Charakterpflanzen Afrikas. II. Band. In: Engler A, Drude O (eds) Die Vegetation der Erde - Sammlung pflanzengeographischer Monographien, vol. 9. Wilhelm Engelmann, Leipzig, pp $1-460$

Gwyne MD (1966) Conservation of plant association on Socotra. East Africa Agriculture and Foresty Research Organization, Nairobi

Jankalski S (2008) Subgenera and new combination in Dracaena. Sansevieria $18: 17-21$

Jankalski S (2009) The Sansevieria inflorescence and new sections proposed. Sansevieria 19:8-10

Judd WS (2003) The genera of ruscaceae in the Southeastern United States. Harvard Pap Bot 7:93-149

Judd WS, Campbell CS, Kellogg EA, Stevens PF, Donoghue MJ (2007) Plant systematics: a phylogenic approach, 3rd edn. Sinauer Associates Inc., Sunderland

Jura-Morawiec J, Tulik M (2016) Dragon's blood secretion and its ecological significance. Chemoecology 2016:101-105

Klimko M, Wiland-Szymańska J (2008) Scanning electron microscopic studies of leaf surface in taxa of genus Dracaena L. (Dracaenaceae). Roczn Akad Roln Poznaniu, Bot Steciana 12:117-127
Klimko M, Nowińska R, Wilkin P, Wiland-Szymańska J (2017a) Pollen morphology of some species of the genus Sansevieria Petagna (Asparagaceae). Acta Biol Cracov, Ser Bot 59:63-75. https://doi. org/10.1515/abcsb-2017-0007

Klimko M, Wysakowska I, Wilkin P, Wiland-Szymańska J (2017b) Micromorphology of stamens of some species of the genus Sansevieria Petagna (Asparagaceae). Steciana 21:41-48. https://doi. org/10.12657/steciana.021.005

Lu PL (2012) Systematics, evolution, and biogeography among Dracaenioid genera: Dracaena, Pleomele, and Sansevieria (Asparagaceae). $\mathrm{PhD}$ Thesis, University of Hawai'i, Manoa

Lu PL, Morden C (2010) Phylogenetics of the plant genera Dracaena and Pleomele (Asparagaceae). Bot Orient 7:4-72. https://doi. org/10.3126/botor.v7i0.4385

Lu PL, Morden CW (2014) Phylogenetic relationships among Dracenoid genera (Asparagaceae: Nolinoideae) inferred from chloroplast DNA loci. Syst Bot 39:90-104. https://doi. org/10.1600/036364414X678035

Mansfeld P (2015) Die Systematik der Gattung Sansevieria (Asparagaceae)-ein aktueller Stand. Sansevieria Online 3:20-29

Marrero A (2000) Dracaena tamaranae, el género Dracaena y otros afines: análisis morfológico para un aproximación filogenética. Mus Canario 55:301-332

Marrero A, Almeida Pérez RS (2012) A new subspecies, Dracaena draco (L.) L. subsp. caboverdeana Marrero Rodr. \& R. Almeida (Dracaenaceae) from Cape Verde Islands. J Geobot Res 2:35-40

Marrero A, Almeida RS, González-Martín M (1998) A new species of the wild dragon tree, Dracaena (Dracaenaceae) from Gran Canaria and its taxonomic and biogeographic implications. Bot J Linn Soc 128:291-314

Miller A (1988) Plants of Dhofar. Office of the Adviser for Conservation of the Environment. Diwan of the Royal Court, Muscat

Miller AG, Cope TA (1996) Flora of the Arabian Peninsula and Socotra. In: Miller AG, Cope TA (eds.) Flora of the Arabian Peninsula and Socotra, vol. 1. Edinburgh University, Royal Botanic Garden, Edinburgh and Royal Botanic Garden, Kew. https://doi. org/10.1111/j.1756-1051.1997.tb00300.x

Nadezhdina N, Plichta R, Nadezhdin V, Gebauer R, Jupa R, Habrova $\mathrm{H}$, Madera $\mathrm{P}$ (2015) A comparative structural and functional study of leaf traits and sap flow in Dracaena cinnabari and Dracaena draco seedlings. Funct Pl Biol 42:1092-1105. https://doi. org/10.1071/FP15079

Petroncini S, Marcheselli MP, Bruschi P (2003) Preliminary aspects of the anatomy and genetic variability of Dracaena cinnabari Balf. fil: a threatened endemic species of Socotra Island, South Yemen. J Agric Environm Int Developm 97:185-195

Prychid CJ, Rudal PJ (1999) Calcium oxalate crystals in Monocotyledons: a review of their structure and systematics. Ann Bot (Oxford) 84:725-739

Rudall PJ, Conran JG, Chase M (2000) Systematics of Ruscaceae/ Convallariaceae: a combined morphological and molecular investigation. Bot J Linn Soc 134:73-92. https://doi. org/10.1111/j.1045.8339.2000.tb02346.x

Staples GW, Herbst DR (2005) A Tropical Garden Flora. Bishop Museum Press, Honolulu

Täckholm V (1956) Student's Flora of Egypt. Anglio-Egyptian Bookshop, Cairo

Thulin M (1995) Dracaenaceae. In: Thulin M (ed.) Flora of Somalia, vol. 4. Angiospermae (Hydrocharitaceae-Pandanaceae). Royal Botanic Garden, Kew, pp 27-30

Walker C (1999) A tale of dragons - the pachycaul species of Dracaena. Brit Cactus Succ J 17:171-177

Wiland-Szymańska J, Klimko M (2005) Differentiation of leaf anatomy of the genera Dracaena L. and Sansevieria Thunb. (Dracaenaceae). In: Anonymous (ed) Abstracts, XVII International Botanical Congress, 12-16 July 2005, Vienna, Austria, p 328 
Wilkin P, Suksathan P, Keeratikiat P, Welzen P, Wiland-Szymańska $J$ (2012) A new threatened endemic species from central and northeastern Thailand, Dracaena jayniana (Asparagaceae: tribe Nolinoideae). Kew Bull 67:697-705. https://doi.org/10.1007/ s112225-012-9412-2

Wilkin P, Suksathan P, Keeratikiat P, Welzen P, Wiland-Szymańska J (2013) A new species from Thailand and Burma Dracaena kaweesakii Wilkin \& Suksathan (Asparagaceae subfamily Nolinoideae). PhytoKeys 26:101-112. https://doi.org/10.3897/phyto keys@5335

Wu ZY, Raven PR (1994) Flora of China, vol. 24. Beijing Science Press, Beijing 